\title{
EFEKTIVITAS IMPLEMENTASI CBT PADA SISWA AKUNTANSI DI SMKN A MADIUN
}

\author{
Bella Putri Oktavia ${ }^{1}$ \\ Bellaputrioktavia0510@gmail.com, Pendidikan Akuntansi, Universitas PGRI Madiun
}

Satrijo Budi Wibowo ${ }^{2}$

Satrijobudiwibowo@gmail.com, Pendidikan Akuntansi, Universitas PGRI Madiun

Elly Astuti ${ }^{3}$

ellyastuti@unipma.ac.id, Pendidikan Akuntansi, Universitas PGRI Madiun

\begin{abstract}
Abstrak
Penelitian ini bertujuan untuk mengetahui tingkat efektivitas pelaksanaan program CBT pada peserta didik kelas X Akuntansi 3 di SMKN A Madiun. Jenis penelitian kualitatif studi kasus. Pengumpualn data dilakukan dengan observasi, wawancara, dan dokumentasi. Penilaian efektivitas program didasarkan pada keakuratan, ketepatan waktu, keunggulan program, ketepatan sarana prasarana dan upaya pengembangan program. Hasil dari penelitian ini menunjukkan bahwa pelaksanaan program CBT sudah dinilai efektif, namun belum dapat meningkatkan hasil belajar peserta didik karena kurangnya tingkat pemahaman peserta didik terhadap mata pelajaran yang diujikan menggunakan aplikasi CBT. Secara umum aplikasi CBT yang dimiliki sekolah memiliki keunggulan papperless dan lebih efisien.
\end{abstract}

Kata Kunci : Efektivitas., Computer Based Test (CBT)., dan Hasil Belajar.

\section{EFFECTIVENESS OF THE CBT PROGRAM IMPLEMENTATION IN ACCOUNTING STUDENTS AT SMKN A MADIUN}

\begin{abstract}
This study aims to determine the level of effectiveness of the CBT program implementation in class X Accounting 3 students at Madiun Vocational High School A. Type of case study qualitative research. Data collection is done by observation, interviews, and documentation. The assessment of program effectiveness is based on accuracy, timeliness, program excellence, accuracy of infrastructure and program development efforts. The results of this study indicate that the implementation of the CBT program has been assessed as effective, but has not been able to improve student learning outcomes because of the lack of understanding of students in the subjects tested using CBT applications. In general, the application of CBT owned by schools has the advantage of paperless and more efficient.
\end{abstract}




\section{PENDAHULUAN}

Pembelajaran menggunakan e-earning saat ini memberikan perubahan besar dalam dunia pendidikan (Tawafak, Romli, Malik, Shakir, \& Farsi, 2019). E-learning menjadi sebuah pilihan karena semakin besarnya kebutuhan akan pembelajaran jarak jauh (Eom \& Ashill, 2018). Pembelajaran di ruang kelas yang terbatas akan waktu dan tempat, menjadikan e-learning semakin diminati. Penggunaan aplikasi e-learning menyediakan fleksibilitas ruang, waktu bahkan bisa jadi tidak mengenal batasan usia untuk belajar. Wong, Li, Wong, \& Yau (2017) mendokumentasikan bahwa penggunaan media E-learning dalam pembelajaran akuntansi sangat efektif karena memungkinkan siswa untuk berbagi pengalaman yang mendorong terciptanya pembelajaran seumur hidup.

Beberapa aplikasi e-learning mulai banyak dikembangkan untuk mendukung kebutuhannya yang semakin luas. Hasil dari penerapan aplikasi tersebut dalam pembelajaran juga memberikan dampak yang positif terhadap siswa. Laily (2017) mengembangkan flipbook berbasis buku digital untuk pembelajaran, serta menunjukkan media tersebut sangat layak untuk digunakan. Oktaviani, Siswandari, \& Muchsini (2019) menunjukkan bahwa penggunaan edmodo mampu meningkatkan hasil pembelajaran akuntansi pada siswa SMK. Maiziani (2016) mendokumentasikan bahwa CBT memberi manfaat bagi peserta didik dalam melaksanakan ujian berbasis komputer. Hal - hal yang disusun pada CBT dirancang untuk peserta didik agar mudah dalam mengoperasikannya dengan diadakannya seperti batasan waktu pengerjaan soal dan sistem menampilkan soal secara random, maka dapat mengurangi kerjasama antar peserta didik.

SMK A di Madiun merupakan salah satu contoh sekolah yang telah menggunakan e-learning untuk menunjang pelaksanaan kurikulum 2013. Berdasarkan observasi dan wawancara awal kepada beberapa pihak, ditemukan bahwa penggunaan CBT ini sangat disukung oleh seluruh civitas akademika yang ada di sekolah tersebut. Kelayakan penggunaan CBT sebagai media pembelajaran juga sudah didokumentasikan oleh Novrianti (2014). menyatakan mengenai hasil penelitiannya bahwa dengan kemajuan dalam

CBT banyak digunakan oleh sekolah karena keunggulan yang dimilikinya jika dibandingkan hanya menggunakan media konvensional. Penggunaan CBT dapat meminimalisir tindak kecurangan dalam ujian (Balan, Sudarmin, \& Kustiono, 2017; Khori \& Harimurti, 2018; Tedyyana \& Danuri, 2017). CBT juga dapat digunakan sebagai alat evaluasi pembelajaran terkomputerisasi sehingga membantu guru dalam melaksanakan evaluasi pembelajran (Lidya Wati, Kasmawi, \& Mawarni, 2018; Pakpahan, 2016). Keunggulan CBT tersebut tentu berdampak positif untuk peningkatan mutu pendidikan di sekolah (Agustina, 2016). Nurhidayat (2016) menyatakan bahwa implementasi pelaksanaan program CBT dapat dilakukan dengan tiga tahapan yaitu tahap persiapan meliputi sosialisasi program, data sekolah, penetapan infrastruktur dan lain sebagainya, yang kedua tahap pengelolaan meliputi pengelolaan sarana prasarana, yang ketiga tahap pelaksanaan meliputi pelaksanaan pra ujian, pelaksanaan ujian dan pengolahan hasil ujian.

Berdasarkan pemaparan diatas, dapat diketahui penggunaan e-leaning dengan beberapa aplikasi ataupun CBT diketahui efektif untuk meningkatkan hasil belajar siswa. Namun demikian Eom \& Ashill (2018) menjelaskan bahwa keberhasilan pelaksanaan e-learning tergantung pada kualitas perencanaan pembelajaran, instruktur, motivasi, komunikasi antara siswa dengan siswa, komunikasi siswa dengan guru, capaian pembelajaran yang diharapkan dan self regulated learning. Thai, Wever, \& Valcke (2017) menjelaskan bahwa model flipped classroom yang merupakan gabungan 
antara e-learning dan tatap muka konvensional akan menghasilkan kualitas pembelajaran yang lebih baik daripada hanya memilih salah satunya saja. Untuk itu penelitian ini ditujukan untuk mengetahui efektifitas pelaksanaan Program Computer Based Test (CBT) yang dilaksanakan oleh SMKN A Madiun serta mengetahui faktor faktor penghambat dan pendukung tingkat efektifitas pelaksanaan Program Computer Based Test (CBT) tersebut.

\section{Model Pembelajaran Akuntansi}

\section{TINJAUAN PUSTAKA}

Pada mulanya pembelajaran akuntansi ditujukan untuk memenuhi ujian profesional. Silabus, modul, materi semuanya ditujukan untuk kelulusan program ujian tersebut, sehingga terkesan pendidikan akuntansi yang berlangsung adalah transfer pengetahuan kepada peserta didik (Wong et al., 2017). Seiring dengan perkembangan bisnis yang semakin pesat, beberapa teknologi untuk akuntansi mulai berkembang. Perkembangan tersebut tentu mendorong perubahan fokus dalam pendidikan akuntansi.

Sinkronisasi materi antara lingkungan pendidikan dan kebutuhan dunia usaha dan industri yang kurang seimbang, menjadikan kebutuhan untuk belajar semakin tinggi tanpa batasan ruang dan waktu. Dalam rangka memenuhi kebutuhan tersebut, muncullah aplikasi penunjang kegiatan bealajar yang dapat diakses kapanpun dan dimanapun dengan menggunakan bantuan e-learning.

Sistem pendekatan yang digunakan dalam e-learning adalah seperangkat sistem interdependen yang dinamis untuk berinteraksi secara bersama-sama yang meliputi input, proses dan output (Eom \& Ashill, 2018). Inti utama dalam pelaksanaan e-learning adalah pemilihan aplikasi yang tepat. Aplikasi yang tepat untuk pembelajaran kolaboratif akan berdampak positif baik kepada guru ataupun siswa untuk mencapat tujuan pembelajarannya (Sumaryati, Joyoatmojo, Wiryawan, \& Suryani, 2020).

\section{Evaluasi Efektivitas E-Learning dalam Program Akuntansi}

Beberapa penelitian terdahulu telah mendokumentasikan bahwa penggunaan elearning berdampak positif terhadap peningkatan hasil belajar siswa (Nuris \& Laily, 2017; Oktaviani et al., 2019; Sumaryati et al., 2020; Tawafak et al., 2019; Wong et al., 2017). Hal ini dibuktikan dengan pencapaian aspek kognitif siswa yang meningkat setelah menggunakan e-learning. Namun demikian Thai, Wever, \& Valcke (2017) menjelaskan bahwa model flipped classroom yang merupakan gabungan antara e-learning dan tatap muka konvensional akan menghasilkan kualitas pembelajaran yang lebih baik daripada hanya memilih salah satunya saja.

Eom \& Ashill (2018) menjelaskan bahwa keberhasilan sistem e-learning dalam pembelajaran sangat bergantung pada enam faktor. Faktor-faktor tersebut adalah: kualitas rancangan pembelajaran, instruktur, motivasi, komunikasi antar siswa, komunikasi antara instruktur dan siswa, self regulated learning dan capaian pembelajaran yang diharapkan.

\section{METODE}

Jenis penelitian ini menggunakan jenis penelitian kualitatif studi kasus dengan tehnik pengumpulan data yang bersumber dari data primer dan data sekunder. Data primer yaitu data yang diperoleh melalui observasi yang meliputi observasi terkait program CBT misalnya aplikasi yang digunakan, jaringan wifi dan media yang digunakan untuk pelaksanaan CBT, yang kedua wawancara dan dokumentasi meliputi hasil atau nilai peserta didik setelah pelaksanaan CBT. Wawancara dilakukan kepada 
WAKA Kurikulum, guru dan peserta didik kelas A Akuntansi 3 SMKN X Madiun, sedangkan data sekunder diperoleh dari daftar hasil belajar peserta didik setelah pelaksanaan CBT.

\section{HASIL DAN PEMBAHASAN}

CBT yang telah diterapkan oleh sekolah ini sudah dimulai dari tahun 2013 hingga sekarang. Awal penerapan program CBT hanya diberlakukan untuk kelas XII saja, namun seiring berjalannya waktu pelaksanaan program CBT ini mulai diterapkan secara menyeluruh dari kelas X hingga kelas XII. CBT digunakan sebagai alat evaluasi pembelajaran di sekolah tersebut. Sarana yang digunakan untuk penerapan program CBT dari tahun 2013 hingga kini berbeda, awal penerapan menggunakan komputer sekolah namun satu tahun terakhir ini mulai diterapkan dengan menggunakan laptop, notebook dan gadget atau android dengan teknis pelaksanaan mengunduh aplikasi CBT SMKN A Madiun dan login untuk mulai mengerjakan.

Penelitian ini dilaksanakan di salah satu kompetensi keahlian di SMKN A Madiun yaitu di bidang akuntansi dengan tujuan untuk mengetahui sejauhmana tingkat efektivitas pelaksanaan program CBT pada peserta didik kelas X Akuntansi, beberapa kriteria yang digunakan peneliti untuk mengukur tingkat keefektivitasan program yaitu keakuratan, ketepatan waktu, keunggulan program, ketepatan sarana prasarana dan pengembangan. Keakuratan adalah penyampaian informasi secara detail dan jelas mengenai pelaksanaan program CBT. Dalam penyampaian informasi mengenai pelaksanaan program CBT di SMKN A Madiun dari pihak sekolah kepada pihak - pihak terkait sudah sangat jelas, bahkan pihak sekolah sendiri mengadakan pelatihan dan simulasi (Gambar 1) sebelum pelaksanaan program CBT. Hal ini didasarkan kepada hasil wawancara dengan ke empat informan :

Informan 1: Waka Kurikulum menyampaikan bahwa "informasi pelaksanaan program CBT sudah disampaikan secara jelas kepada pihak-pihak terkait melalui beberapa tahapan salah satunya pelatihan dan simulasi”.

Informan 2: Salah satu guru mata pelajaran sekaligus wali kelas menyampaikan bahwa "informasi tersampaikan secara jelas melalui pelatihan dan simulasi program CBT"

Informan 3: Siswa berinisial W mengatakan bahwa "penyampaian informasi berkenaan dengan pelaksanaan program CBT sudah tersampaikan secara jelas kepada peserta didik ditambah dengan pelatihan dan simulasi sebelum pelaksanaan program CBT".

Informan 4: Siswa berinisial V menjelaskan mengenai penyampaian pelaksanaan program CBT sudah tersampaikan secara jelas melalui pelatihan CBT. 


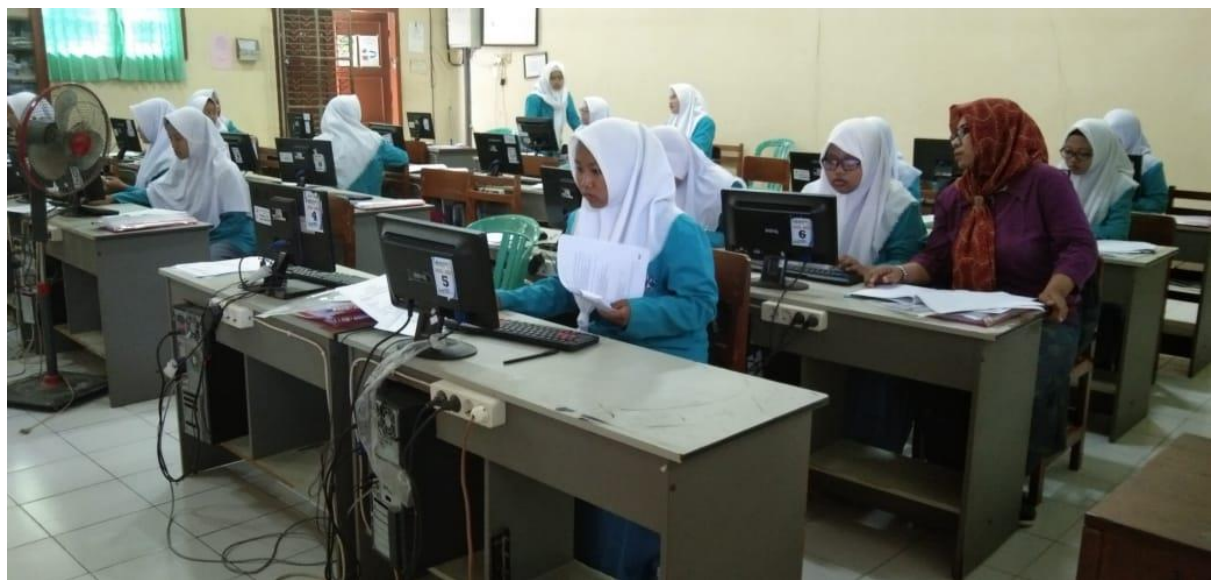

Gambar 1. Pengenalan, sosialisasi dan pendampingan awal penggunaan CBT

Ketepatan waktu pelaksanaan program CBT di SMKN 5 Madiun didasarkan pada pertimbangan tingkat kesulitan mata pelajaran. Berdasarkan wawancara yang telah peneliti lakukan mendapatkan hasil dari ke empat informan sebagai berikut

Informan 1: Waka Kurikulum menjelaskan bahwa "alokasi waktu menyesuaikan tingkat kesulitan mata pelajaran yang diujikan.

Informan 2: Seorang guru menjelaskan bahwa pengalokasian waktu yang digunakan untuk pelaksanaan program CBT sudah mempertimbangkan dari tingkat kesulitan dalam pengerjaan soal disuatu mata pelajaran.

Informan 3: siswa berinisial W menjelaskan bahwa waktu yang diberikan untuk pelaksanaan program CBT sudah sangat cukup karena dari tipe soal yang menggunakan model pilihan ganda.

Informan 4: siswa berinisial V mengatakan bahwa waktu yang ditentukan oleh pihak sekolah pasti sudah berdasarkan pertimbangan yang tepat

Berdasarkan observasi yang dilakukan, alokasi waktu yang digunakan oleh CBT lebih singkat dan cepat. Sedangkan ujian tertulis menggunakan model konvensional, membutuhkan waktu sedikit lebih lama karena peserta didik harus menuliskan jawaban dari setiap pertanyaan dilembar kertas yang disediakan. Dalam penggunaan CBT, peserta didik hanya mengklik salah satu jawaban dari setiap opsi jawaban dalam satu pertanyaan. Ketepatan waktu (timeliness) sudah ditetapkan melalui pertimbangan yang menyesuaikan tingkat kesulitan mata pelajaran, dengan alokasi waktu 90 menit untuk mata pelajaran yang ringan dan 20 menit untuk mata pelajaran yang terdapat proses perhitungannya.

Keunggulan program, Program CBT di SMKN A Madiun sudah menggunakan aplikasi yang diperuntukkan hanya untuk civitas akademikanya dengan nama CBT SMKN A Madiun, sehingga pada saat pelaksanaan hanya memerlukan login untuk masuk kedalam program CBT. Aplikasi CBT SMKN A Madiun bisa didownload melalui gadget atau android yang akan digunakan sebagai alat pelaksanaan program CBT. Namun demikian, masih terdapat beberapa kelemahan program ini selama pengimplementasiannya di sekolah yaitu sinyal jaringan yang hilang atau eror, gadget yang tiba-tiba eror, sering log out secara sendirinya. 

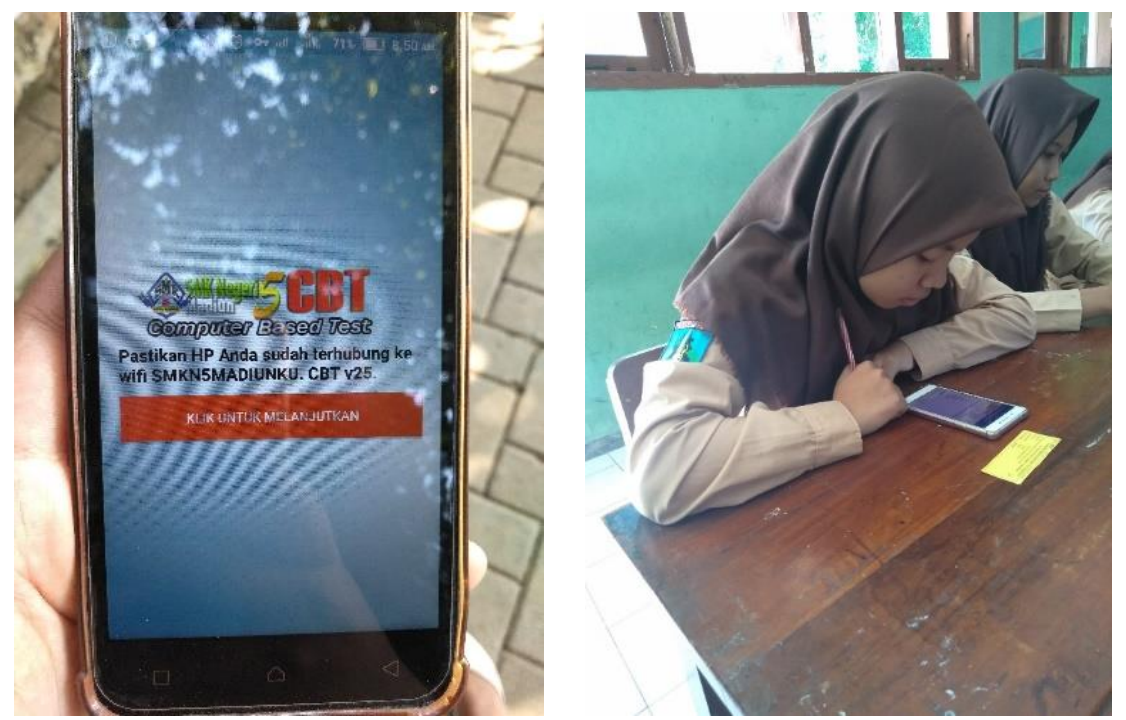

Gambar 2. Siswa sedang menggunakan aplikasi CBT

Ketepatan penggunaan sarana prasarana, keterlibatan sarana prasarana sebagai pendukung pelaksanaan program CBT. SMKN A Madiun dalam penggunaan sarana prasarana sekolah untuk mendukung pelaksanaan program CBT sudah sangat baik mulai dari segi penggunaan ruang hingga jaringan. Dari hasil wawancara keunggulan program dari segi penggunaannya lebih efektif dan efisien, alat yang digunakan yaitu gadget milik peserta didik, menghemat penggunaan paperless. Gadget peserta didik akan dikoneksikan kepada jaringan wifi yang disediakan oleh sekolah. Hasil wawancara ini didukung oleh pendapat dari beberapa informan.

Informan 1: menurut Waka Kurikulum keunggulan program CBT secara segi penggunaannya lebih efektif dan efisien dibandingkan dengan penggunaan paperless, namun secara khusus keunggulan program terdapat dalam aplikasi yang digunakan untuk pelaksanaan CBT dan juga alat yang digunakan untuk pelaksanaan program CBT berupa gadget atau android.

Informan 2: menurut guru mata pelajaran mengatakan bahwa keunggulan program lebih efektif dan efisien.

Informan 3 menyampaikan bahwa keunggulan pelaksanaan program CBT mengurangi tingkat kecurangan peserta didik dan hasil ujian dapat diketahui secara langsung setelah selesai mengerjakan.

Informan 4 berpendapat bahwa CBT memiliki kelebihan untuk menghemat waktu, mengurangi kecurangan dan mengurangi penggunaan kertas.

Pelaksanan program CBT tidak lepas dari sarana prasarana sebagai penunjang keberhasilan pelaksanaan program CBT. Sarana prasarana yang digunakan dalam pelaksanan program CBT sudah memenuhi kebutuhan peserta didik dalam pelaksanan program. Sarana prasarana yang digunakan meliputi ruangan kelas, meja kursi, wifi, dan lain sebagainya.Ketepatan penggunaan sarana prasarana keterlibatan sarana prasarana sebagai pendukung pelaksanaan program CBT. SMKN A Madiun dalam penggunaan sarana prasarana sekolah untuk mendukung pelaksanaan program CBT sudah sangat baik mulai dari segi penggunaan ruang hingga jaringan. Hal ini didukung oleh pernyataan dari beberapa informan yang konsisten menunjukkan jawaban yang sama. 
Waka Kurikulum SMKN A Madiun : Bagi sarana prasarana sangat mendukung karena tahun ini kami menerapkan program CBT dengan menggunakan gadget atau android peserta didik, sehingga sedikit menimbulkan rasa yang berbeda dalam kegiatan program karena aktivitas dengan gadget atau android sudah familiar dikalangan peserta didik.

Informan 2 menjelaskan mengenai sarana prasarana untuk pelaksanaan program CBT sudah baik dan memenuhi kebutuhan peserta didik selama pelaksanaan program CBT.

Informan 3 berpendapatan mengenai sarana prasarana di SMKN 5 Madiun sudah memenuhi kebutuhan pelaksanaan program CBT.

Informan 4 mengatakan bahwa sarana prasarana sudah sangat mendukung.

Upaya selalu dilakukan untuk memperbaiki kekurangan dari pelaksanaan program. Upaya perbaikan tidak hanya membahas mengenai perbaikan secara teknis akan tetapi juga mengeani evaluasi pembelajaran yang merupakan hasil dari pelaksanaan program. Dari hasil wawancara diperoleh bahwa untuk hasil belajar peserta didik saat ini setelah pelaksanaan program CBT sangat menurun, upaya yang dilakukan pihak sekolah mencari tahu penyebab dari menurunnya hasil pembelajaran yang diperoleh peserta didik melalui program CBT. Walaupun penggunaan CBT ini tidak mampu meningkatkan aspek kognitif siswa, namun jika diobservasi lebih lanjut, CBT dapat meningkatkan aspek afektif siswa. Peningkatan aspek afektif ditunjukkan dengan peningkatan kejujuran siswa dalam evaluasi pembelajaran yaitu semakin sedikit tindak kecurangan seperti mencotek teman saat ujian berlangsung, bahkan hampir tidak ada.

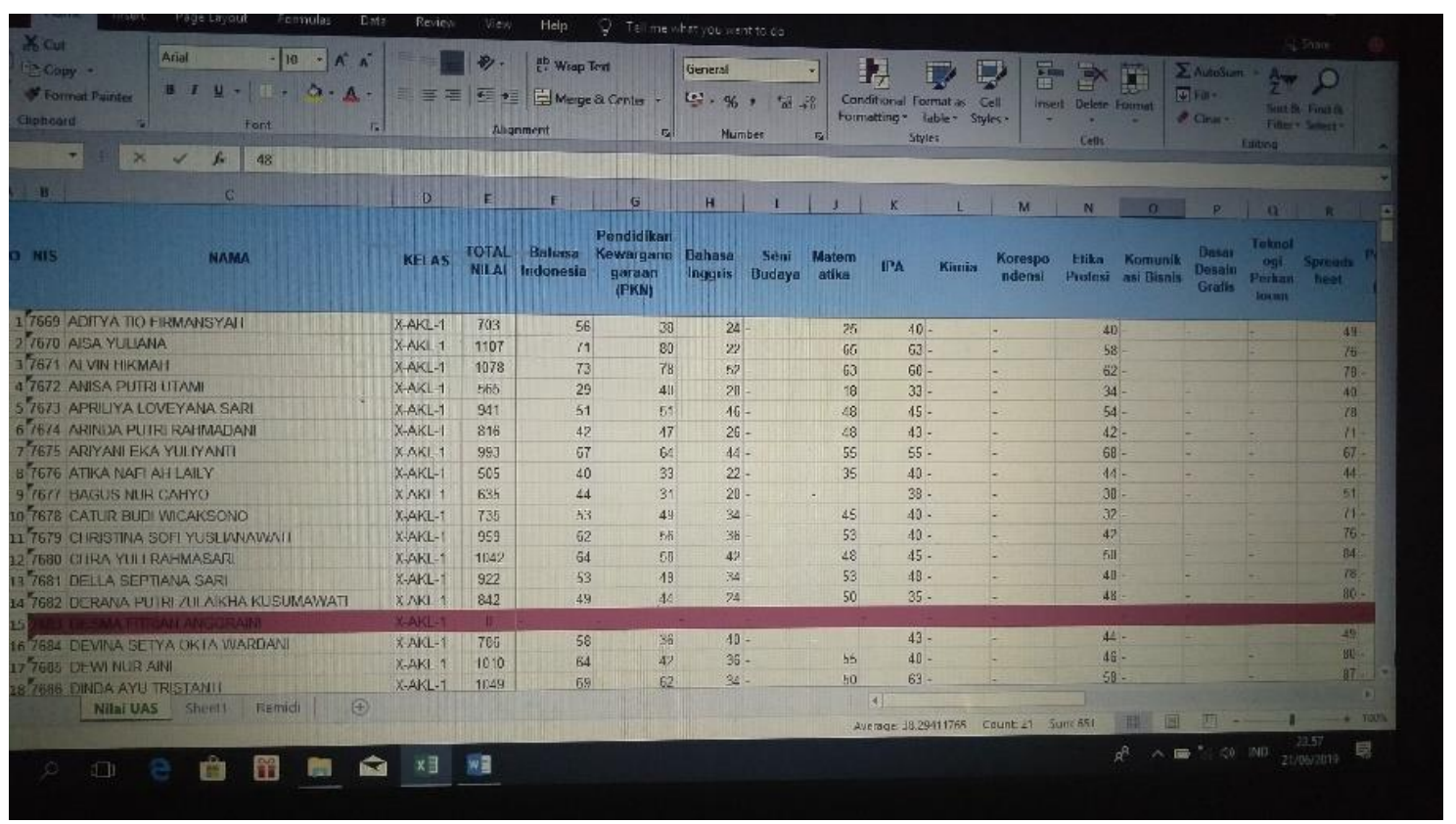

Gambar 3. Hasil evaluasi pembelajaran siswa menggunakan CBT

Waka Kurikulum SMK A Madiun yaitu Mengenai dampak dari pelaksanan CBT terkait evaluasi pembelajaran untuk saat ini dari segi hasil nilai peserta didik menurun. Namun dari menurunnya hasil peserta didik kita pihak sekolah tetap mencari penyebab karena menurunnya nilai peserta didik bisa disebabkan oleh beberapa faktor kecuali dari program 
CBT itu sendiri, misalnya karena ketidakpahaman terhadap mata pelajaran yang diujikan atau hanya memilih bebas saat mengerjakan soal

Informan 1: Kami pihak sekolah selalu mengupayakan untuk mengatasi permasalahan yang timbul melalui Tim IT dan Tim Tulmen yang selalu siap memperbaiki masalah saat pelaksanaan program CBT, misalnya jika disuatu ruangan wifinya tidak dapat terhubung maka tim IT dan tim Tulmen yang memperbaikinya. Kalau untuk peningkatan kualitas program, pihak sekolah melakukan pembaharuan dari segi alat atau media pelaksanaan program CBT dan pembaharuan aplikasi CBT SMKN 5 Madiun. Misalnya, tahun lalu masih menggunakan komputer namun karena dianggap belum bisa memenuhi kebutuhan peserta didik maka tahun ini diterapkan dengan menggunakan gadget masing-masing peserta didik. Mengenai dampak dari pelaksanan CBT terkait evaluasi pembelajaran untuk saat ini dari segi hasil nilai peserta didik menurun. Namun dari menurunnya hasil peserta didik kita pihak sekolah tetap mencari penyebab karena menurunnya nilai peserta didik bisa disebabkan oleh beberapa faktor kecuali dari program CBT itu sendiri, misalnya karena ketidakpahaman terhadap mata pelajaran yang diujikan atau hanya memilih bebas saat mengerjakan soal.

Informan 2: Setiap menjelang pelaksanaan program CBT selalu diadakan simulasi atau pelatihan terlebih dahulu dan dampaknya bagi kami para guru pastinya mempercepat penilaian, mengupload nilai. Jika bagi siswa terkait dengan evaluasi pembelajaran, dari segi hasil untuk saat ini menurun.

Informan 3: Untuk evaluasi belajar saya setelah menggunakan program CBT yaitu nilai saya banyak yang menurun, namun bukan karena kesalahan program tetapi karena faktor dari diri saya yang tidak siap dengan mata pelajaran yang akan diujikan.

Informan 4: Setelah pelaksanaan program CBT, nilai saya banyak yang menurun karena saya kurang belajar pada mata pelajaran yang akan diujikan

Efektivitas adalah kesesuaian hasil dengan kriteria atau prosedur yang menjadi pedoman dengan kata lain bahwa pekerjaan yang dilakukan sudah mampu menyatakan tujuan organisasi dalam aspek program yang dikerjakan. CBT merupakan sistem berbantuan komputer dengan jaringan internet guna membantu guru dalam pelaksanaan penilaian, penskoran, pelaksanaan tes maupun efektifitas pelaksanaan. Berdasarkan penelitian yang telah dilakukan oleh peneliti mengenai efektivitas pelaksanaan program CBT pada peserta didik kelas X Akuntansi di SMKN A Madiun, maka dapat disimpulkan bahwa pelaksanaan program CBT di SMKN A Madiun telah berjalan dengan efektif. Adapun kendala yang dihadapi adalah

\section{SIMPULAN}

Bedasarkan analisis dan pembahasan yang telah dilakukan dapat disimpulkan bahwa implementasi program CBT dalam kegiatan pembelajaran di SMKN 5 Madiun sudah efektif karena telah memenuhi kriteria yang ditetapkan yang meliputi; keakuratan informasi, ketepatan informasi serta sarana dan prasarana yang mendukung. Walaupun ada beberapa kendala yang dihadapi dalam proses implementasi tersebut, namun dirasa kekurangan tersebut tidak berdampak signifikan karena untuk menjelankan suatu program yang sesuai dengan karakteristik dan kebutuhan organisasi membutuhkan waktu yang cukup lama dan perlu diperbarui secara berkesinambungan untuk menyesuaikan pola bisnis yang dimiliki. 
Berdasarkan kesimpulan hasil penelitian mengenai efektivitas pelaksanaan program CBT pada peserta didik kelas X Akuntansi di SMKN A Madiun maka penulis menyampaikan saran sebagai berikut: Dalam pelaksanaan program CBT diharapkan untuk memperhatikan hasil belajar peserta didik sehingga di pelaksanaan berikutnya hasil peserta didik sudah tidak menurun lagi. Meningkatkan kualitas jaringan Wifi sehingga pada saat pelaksanaan tidak terjadi jaringan yang trouble. Keterbatasn waktu penelitian, menjadikan sudut pandang yang digunakan dalam naskah ini dalam ruang lingkup relatif sempit. Peneliti juga terbatas dalam memperoleh informasi mengenai kondisi dan stabilitas jaringan wifi yang dimiliki oleh sekolah. Saran untuk penelitian selanjutnya, peneliti menyarankan untuk memperluas lingkup penelitiannya dengan subjek penelitian yang berbeda guna menambah wawasan dan informasi yang lebih luas.

\section{DAFTAR PUSTAKA}

Agustina, D. A. S. (2016). Perancangan Aplikasi Computer Based Test (CBT) Berbasis Web (Studi Kasus di SMP Negeri 2 Kuta - Bandung). Teknologi Informasi Dan Komputer, 2(1), 1-14.

Balan, Y. A., Sudarmin, \& Kustiono. (2017). Pengembangan Model Computer Based Test (CBT) Berbasis Adobe Flash untuk Sekolah Menengah Kejuruan. Innovative Journal of Curriculum and Educational Technology, 6(1), 36-44. https://doi.org/10.15294/ijcet.v6i1.15574

Eom, S. B., \& Ashill, N. J. (2018). A System's View of E-Learning Success Model. Decision Sciences Journal of Innovative Education, 16(1), 42-76.

Khori, A., \& Harimurti, R. (2018). Pengembangan Ujian Berbasis Komputer Sebagai Perangkat Ulangan Harian di SMKN 1 Kota Mojokerto. IT - EDU, 03(01), 54-63.

Laily, N. (2017). Developing Digital Learning Media in Accounting. International Journal of Engineering \& Scientific Research, 5(1), 18-29.

Lidya Wati, L., Kasmawi, K., \& Mawarni, S. (2018). Implementasi Computer Based Test (Cbt) Di Sekolah Menengah Kejuruan. Batoboh, 3(1), 83. https://doi.org/10.26887/bt.v3i1.491

Maiziani, F. (2016). Efektivitas Computer Based Testing. Kiprah, 4(1), 15-32.

Novrianti. (2014). Pengembangan Computer Based Testing (CBT) Sebagai Alternatif Teknik Penilaian Hasil Belajar. Lentera Pendidikan, 17(1), 34-42.

Nurhidayat, A. (2016). Implementasi Ujian Nasional Berbasis Komputer atau Computer Based Test di SMA Negeri 1 Wonosari. Administrasi Pendidikan, 1-16.

Nuris, D. M., \& Laily, N. (2017). The Effect of Learning Media on Accounting Student's Achievement. https://doi.org/10.31227/osf.io/jv2wx

Oktaviani, A., Siswandari, S., \& Muchsini, B. (2019). Keefektifan Penerapan E-Learning Edmod Untuk Meningkatkan Hasil Belajar Akuntansi Siswa. Jurnal Tata Arta, 5(2), 7587.

Pakpahan, R. (2016). Model Ujian Nasional Berbasis Komputer: Manfaat Dan Tantangan Computer-Based National Exam Model: Its Benefits and Barriers. Jurnal Pendidikan Dan Kebudayaan, 1(1), 1-18.

Sumaryati, S., Joyoatmojo, S., Wiryawan, S. A., \& Suryani, N. (2020). Potential of E-CoPAL Strategy to Improve Analytical Problem Solving and Teamwork Skills in Accounting Education. International Journal of Instruction, 13(2), 721-732.

Tawafak, R. M., Romli, A., Malik, S. I., Shakir, M., \& Farsi, G. Al. (2019). A Systematic Review of Personalized Learning: Comparison between E-Learning and Learning by 
Coursework Program in Oman. IJET, 14(9), 93-104.

Tedyyana, A., \& Danuri, D. (2017). Computer Based Test Untuk Seleksi Masuk Politeknik Negeri Bengkalis. Digital Zone: Jurnal Teknologi Informasi Dan Komunikasi, 8(2), 114-124. https://doi.org/10.31849/digitalzone.v8i2.636

Thai, T. N. T., Wever, B. De, \& Valcke, M. (2017). The impact of a flipped classroom design on learning performance in higher education: Looking for the best "blend" of lectures and guiding questions with feedback. Computers \& Education, 1-26. https://doi.org/10.1016/j.compedu.2017.01.003

Wong, B. T., Li, K. C., Wong, B. Y., \& Yau, J. S. (2017). E-learning in Accounting Programmes in Hong Kong: Evolution and Effectiveness. ICBL, 2, 97-105. https://doi.org/10.1007/978-3-319-59360-9 